\title{
The manifestations of digital literacy in social media among Indonesian youth
}

\author{
Acintya Ratna Priwati, Avin Fadilla Helmi \\ Faculty of Psychology, Universitas Gadjah Mada, Indonesia \\ Corresponding author: acintya.ratna.p@ugm.ac.id
}

\section{ARTICLE INFO}

Article history

Received July 14, 2020

Revised December 12, 2020

Accepted February 22, 2021

Keywords

confirmation;

cross-check;

digital literacy;

information sharing;

social media.

\begin{abstract}
Digital literacy capability is a must in the era of internet access, especially in the use of social media. All internet users, especially university students, must practice digital literacy. This study aims to found the common forms of university students' digital literacy behavior when using social media. This study uses a mixed-method approach as it consists of data search using a digital literacy scale, an open-ended questionnaire, and interviews with university students in Yogyakarta. The results of this study indicate that respondents with high digital literacy levels conduct a process of evaluating truthful information by checking trusted sources of information directly and discussing their findings with significant others. The likelihood and ability to evaluate information correctly is affected by family background, formal education, and negative hoax impact awareness. The study also found that after respondents perform across (double) checks, they will usually forward the information, also known as doing a repost. This research implies a description of digital literacy behavior carried out by students in Yogyakarta; with this study, digital literacy behavior expects to provide an overview of information technology policymakers.
\end{abstract}

\section{Introduction}

Internet is one of the resources people often use in daily life for various purposes, such as communicating, establishing and maintaining relationships, and carrying out transactions (Tapscott, 2009). Internet usage as computer-mediated communication is often chosen over face-to-face communication since it facilitates communication faster, which is ultimately more practical for many people (Walther, 2011). However, the internet can also pose a threat to its users. For example, as Indonesia entered a recent political upheaval year, it was inundated by internet hoaxes and messages containing hate speech. $65 \%$ of Indonesians believe in and trust what they see and read on the internet (CIGI-IpSos, 2017), making it a highly-trusted commodity. In particular, the Republic of Indonesia's Government has been campaigning intensively on digital literacy (Kominfo, 2014). Individuals should have the ability to understand how to use technology in useful ways and to understand how large the impact of technology truly is (Wood, 2009), later referred to as digital literacy. The widespread information that is not accompanied by digital literacy skills shows the urgency to conduct digital literacy research in the psychological realm. Several previous studies have linked digital literacy with communication skills (Pietrass, 2007; Warschauer, 2009). In this study, researchers tried to see the dynamics of digital literacy that occur in society.

Digital literacy is defined as an individual's ability to use internet facilities to identify, evaluate and communicate with others (Martin, 2005). These capabilities can be applied when individuals participate in the exchange of information through communication and in the 
creation of digital content (Sharma, Fantin, Prabhu, Guan, \& Dattakumar, 2016), with both software and hardware, also in the context of education, entertainment, and social environment (Ng, 2012). In detail, digital literacy, according to Martin (2005), can be applied in the form of identifying (identification), choosing access, integrating, evaluating, synthesizing from various digital sources, expressing the information obtained, and communicating the information to others. Based on these various definitions, we can conclude that digital literacy describes individuals' ability to use technology within various contexts. Furthermore, according to Ramdhani, Wiradhany, \& Rachmayani (2013), digital literacy reveals four aspects of digital literacy with four Indonesian context abilities. The first ability is instrumental, performed skills when individuals access hard or software. The second ability is to evaluate information, which is done when individuals actively choose the information received and processed. The third ability is to produce information, the ability when individuals can forward or convey information they have, and the last component is social, namely the ability of individuals to empathize with other people's conditions and relate to affective.

Along with the need to have digital literacy emerged, it is needed to know society's digital literacy level and how it is applicable within society. Although digital literacy raises widely, there has not been much information to see the level of digital literacy and its application. Previous research related to digital literacy in Indonesia emphasized digital students' literacy in attending lecture activities (Pratolo \& Solikhati, 2020; Rahmah, 2015), also digital media literacy related to gender perspective (Suwana \& Lily, 2017). This research is an initiation in identifying psychological behaviors related to digital literacy, with a mixedmethod design to asks the actual behavior that individuals apply when they usually get information; thus, it can provide a concrete depiction of the narratives conveyed by respondents. This study aims to determine university students' capability with digital literacy as they represent the majority of internet users in Indonesia (APJII, 2016). University students are expected to have the ability to develop intelligent thinking as well as to act virtuously as agents of change in nation-building. It is hoped that the results of this study will increasingly have a complete picture of digital literacy behavior.

\section{Method}

This research applied a mixed-method design to increase the coverage and depth of research data (Cresswell, 2009). A mixed-method design is created by combining a quantitative approach in the first stage with a qualitative approach as the second and third stages as follows: the first study is a survey using a digital literacy scale adopted from Ramdhani et al. (2013); the second stage in this study presented a number of open-ended questions, allowing respondents to represent their activity about the use of social media (Cresswell, 2009); the third stage is interview were conducted with six respondents, including five participants and one expert to provide in-depth information of the digital literacy forms.

\section{Study 1}

A quantitative study involving 274 university students in Yogyakarta contributing to this study through convenience sampling was conducted. Two hundred female students and 74 male students participated in this study, ranging between 19 to 25 years old from various college majors at 18 universities in Yogyakarta. Yogyakarta was chosen as the study location because of its large internet usage absorption rate of 54\% (APJII, 2016). The digital literacy scale was adapted by Ramdhani et al. (2013) as a basis for measuring their digital literacy levels. This scale was constructed of 15 items based on four aspects of digital literacy: instrumental ability, the ability to evaluate information, the ability to produce information, and an evaluation of social skills. Data were analyzed with SPSS 20 and AMOS. 


\section{Study 2}

The second stage is a qualitative study by presenting a number of open-ended questions to 119 respondents out of 274 as they declared they often share information with others on social media. Participants are allowed to represent their activity using social media by asking about their response after receiving broadcast information and their motivation to forward the information to others.

\section{Study 3}

In study 3, an in-depth interview with five participants was conducted to have deeper information from the previous studies about digital literacy activity. The five participants are currently studying at universities in Yogyakarta, and each interview session was conducted twice to obtain trustworthy data. The five participants were selected based on their high literacy score from study 1 . They were asked about their willingness to be further interviewed and schedule compatibility. The questions posed to participants in this study are: what activities are carried out in social media, what behaviors are carried out spontaneously when obtaining digital information, and what is understood about the need for digital literacy.

Characteristically, these five respondents indicate that they are students who have studied for 1-3 years in tertiary institutions in Yogyakarta city. The four are female and one male. These five respondents are students from several different cities in Indonesia.

\section{Results}

The following is an explanation of the three studies conducted in this research: The first study obtained an overview of the participants' digital literacy level results. Study two uncovered participants' motivation and behavior when receiving messages. While the third study found out about the narrative of action they have done when using social media.

\section{Study 1}

The results show the psychometric properties of the digital literacy scale with Indonesian society's context (see Table 1).

Table 1

The Comparison of Factor Analysis Results

\begin{tabular}{lcc}
\hline & 3 components & 4 components \\
\hline$d f$ & 87 & 84 \\
$p$ & .000 & .000 \\
$G F I$ & .903 & .899 \\
$C F I$ & .926 & .923 \\
$T L I$ & .911 & .904 \\
RMSEA & .076 & .079 \\
\hline
\end{tabular}

The instrument initially consists of four aspects that formed a person's digital literacy. But based on the parametric test in this study, digital literacy is more solid when formed into three aspects. When conducting a confirmatory test, it appears that the aspects that are formed are instrumental ability, the ability to evaluate information, and the ability to generalize information. Through a range of digital literacy scores, it is known that the majority of respondents admit that they have high and very high digital literacy skills, as much as $86.8 \%$ (see Table 2). 
Table 2

Level of Digital Literacy

\begin{tabular}{lcc}
\hline Category & Frequency & Percentage (\%) \\
\hline Very high & 125 & 45.6 \\
High & 113 & 41.2 \\
Moderate & 33 & 12.0 \\
Low & 3 & 1.1 \\
\hline Total & 274 & 100 \\
\hline
\end{tabular}

\section{Study 2}

Collected qualitative data were analyzed using thematic analysis (Krippendorff, 2004). The data categorized based on the specification response in Microsoft Excel and multiple responses analyzed in SPSS. A total of 442 responses were grouped into six behaviors (see Table 3).

Table 3

Participants' Responses after Obtaining Text Messages

\begin{tabular}{lcc}
\hline Behavior & Frequency & Percentage $(\%)$ \\
\hline Shared to others & 117 & 26.5 \\
Etc. & 101 & 22.8 \\
Confirm to the news source & 75 & 17.0 \\
Discuss with friends & 72 & 16.3 \\
Silence & 41 & 9.3 \\
Looking for similar news & 36 & 8.1 \\
\hline Total & 442 & 100 \\
\hline
\end{tabular}

Based on the open-ended questionnaire results, respondents conducted various assessments and activities after obtaining information from the internet. The majority of respondents $(26.5 \%)$ shared the information they obtained from social media by forwarding it to others. Meanwhile, 17\% of respondents said they tried to confirm the truth of the information they were sharing by checking with commonly-read news sources believed to be trustworthy. Furthermore, $16.3 \%$ of respondents indicated that they typically discussed the information with their friends. We further explored the student's most frequent behaviors by asking about their motivation for each behavior. Their reasons are presented in Table 4. The majority of respondents forward messages to let others knowing recent information $(41.1 \%)$.

Table 4

Participants' Motivation for Forwarding Messages to Others

\begin{tabular}{lcc}
\hline Reason & Frequency & Percentage $(\%)$ \\
\hline In order for others to know & 193 & 41.1 \\
Helping others to find out the news & 90 & 19.1 \\
Others & 62 & 13.3 \\
Entertain others & 56 & 11.9 \\
Make the news a topic & 32 & 6.8 \\
Inviting people & 19 & 4.0 \\
Make viral issues & 18 & 3.8 \\
\hline Total & 470 & 100 \\
\hline
\end{tabular}




\section{Study 3}

Five respondents are students who are studying in the college. They have a typical profile that is both educated in universities in Yogyakarta in a variety of different duration (see Table 5).

Table 5

Respondent Profile

\begin{tabular}{clll}
\hline Initial & Sex & College Background & Duration of study \\
\hline A & Female & Public university & $3^{\text {rd }}$ year \\
B & Female & Public university & $2^{\text {nd }}$ year \\
C & Female & Public university & $2^{\text {nd }}$ year \\
D & Male & Public university & $1^{\text {st }}$ year \\
E & Female & Public university & $3^{\text {rd }}$ year \\
\hline
\end{tabular}

In general, the interview results show that respondents are accustomed to deliberately seeking information from social media. Their goal is to get the information as a whole and get different viewpoints that can help them be objective in capturing information. The respondent's statement follows:

"... he could have said so, only if the word did not come from a credible source could be a statement of mere personal opinion. Well...I do not know the data he said, I also do not know the back-up data he has".

Furthermore, the respondents conducted information checking by performing confirmation or exploration activities to make sure he obtained credible information. As the respondent's statement:

"So, it's like ... I'm more likely to seek information from data that has credibility so that I understand the data, such as the budget data used, and .... What it functions for so that everything is clear. I will not be nagging at social media and write, 'the dam is not important blah blah blah', because I know the credible data".

In the process of critiquing the obtained information, respondents refer to several sources that are considered capable of presenting valid information. In general, respondents trust the information contained in websites with interesting user interfaces and positive content, as revealed in the following statement:

"And the longer I'm ..., the more positive, the more I finally believe, because he's in the pack, he attempts to pack it, that's as good as the poster. He never made sensational news like a provocateur. This is a reliable source".

After believing that the information obtained is valid, the respondent will share that information with others (repost):

"... I feel grown enough to be able to choose and sort out which information I should keep and which information I repost. Such things end up making me more careful".

\section{Discussion}

In general, this research was conducted to finding out the real form of digital literacy behavior of young people in the Indonesian context. Hence, it is necessary to have a measuring instrument that is able to measure and explain aspects of digital literacy behavior. Based on the quantitative analysis in study 1 , it can be said that digital literacy is more appropriate in using three components. The three components of factor analysis (instrumental ability, information evaluation ability, and information-generating ability) are represented in this 
study's findings. Based on psychometric parameters, we concluded that the three component parameters of GFI, CFI, and TLI have better scores than the four component parameters, according to Hair, Black, Babin, \& Anderson (2010). GFI, CFI, and TLI are said to be good if they score close to 1.0. Based on comparing the fit index on the digital literacy scale, the index with three aspects of the digital literacy scale is more accurate. The result shows that the ability to evaluate social abilities does not appear in data exploration. This finding can enrich the theoretical foundation in exploring the next digital literacy scale.

Further analysis was carried out based on psychometric testing using the 15 items of the digital literacy scale, items that belong to the ability to produce information and social abilities, positioned to be a part of the information-generation ability. As a parable, one of the items in the social skills aspect: "Appreciating masterworks by giving cite in, hyperlinks, or other ways," is a continuation of the item "Manipulating / changing / transforming data from one format to another (for example from the text to images, from audio to text)" in terms of information-generation ability aspect. Observing Eshet-Alkalai (2004) results, this ability is a part of information reproduction literacy and socio-emotional literacy aspects. When an individual is reproducing information, it automatically predicts the character of the message recipient. Based on two analyzes, it is concluded that the digital literacy scale consists of three aspects.

The digital literacy rate score results from the scale filled out by the respondents in the first stage were found to have a similar result with Wanandhi (2016) study. However, when each dimension of literacy level was compared, the results were found to contradict. Previously, with the same respondents sampling, i.e., students in Yogyakarta, Wanandhi (2016) found that some instrumental dimensions were more prominent than others. This result means respondents were perceived themselves to be superior in operating gadgets to find information, but the score is reversed in other aspects. Meanwhile, this study found the opposite result. Respondents indicated that they have a high enough capability in the other three dimensions: instrumental ability, ability to evaluate information, and ability to informational generalization. Data from study 3 can provide a snapshot of when participants do not consider their instrumental dimension ability to be at the capable level since they could utilize the technology without being professional or digital-savvy. They still have a good consideration in evaluating obtained information through social media. Besides, when this research has been taken, the number of active social media users increases (APJII, 2018). Several cases regarding the negative impact of using social media had appeared in the news. Social media users heard more echoes of the importance of digital literacy.

Further, the results in studies 2 and 3 indicated more detailed behavioral manifestations of the three digital literacy components at the measuring instrument's testing stage. The researcher found an association of common behaviors when accessing information on social media. The similarity between what is written in the open-ended questionnaire and the answers during the interviews shows that respondents are accustomed to sharing information deemed worthy of sharing. It is said to be eligible for sharing as they perform the assessment process on the content encountered. If the content is considered less valid, then they will do a further search.

The action respondents take when using social media is referred to as a cross (double) check. This behavior is regarded as a manifestation of a form of digital literacy. When interpreted literally, the term cross-check describes the behavior of checking data and reports at various points of view and sources to determine its validity and accuracy (merriamwebster.com). Respondents usually complete cross-checks through confirmatory and exploratory behavior because they do not want to be hoax message spreaders. The respondent himself inserted the word 'double' into the term cross-check to obtain the term cross (double) check, stated that he is accustomed to double-checking. The term has the same meaning as finding and checking information to obtain the truth. Also, the word 'double' in this context can represent two dimensions of digital literacy, the instrumental dimension, and the 
informational dimension. When accessing technology, respondents will obtain a variety of information; this is when the informational dimension must be met and where the individual must analyze whether the information is correct and accurate. Consideration in assessing the accuracy and validation of such information is a manifestation of digital literacy behavior (Priwati, 2018).

In the process of a cross (double) checking, respondents look for trusted information sources. Van Deursen \& Van Dijk (2009) found that the problem of obtaining information from the internet is still skill-related; several respondents are still not effective at finding information on the internet. They search for information without using specific keywords, and they obtain information from less reliable sources. In this context, the cross (double) check is reliably defined as consistently presenting valid information and capable of being trusted. In contrast, this study's findings reveal that the research respondents already know their sources of information that are considered capable of providing reliable information. Based on the respondents' statements, the source of reliable information can be divided into several categories. For instance, respondents said that many things indicate that the source of information can be trusted; among these is face validity. As stated by the respondents, packaging information is an interesting format that is considered one form of seriousness in conveying information. This interesting display is a website that contains several articles created by inserting various forms of information that are not limited to the writing. Besides, respondents feel confident in websites that have a neat website framework. When an individual manages his knowledge, he will obtain information from different sources. This demonstrates the individual's ability to think critically and examine the integrity of information from various sources. Respondents feel confident in sources of information that have an interesting look (Bawden, 2008).

Positive-content validity is essential for the participants to prioritizing information obtained based on the validity of the appearance. It contains many articles and positively charged ratings. The existence of a positive assessment reinforces the respondent's belief that the information source is not based on sensational issues. Participants also trust information that is based on factual data, referring as competencies-trust. Respondents consider others who have expertise or knowledge of the topics covered. The individual's competencies are directly proportional to the beliefs held of his ability (Helmi, 2010). Individual reliability cannot be equated with probability because reliability is only obtained when the individual's actions are predictable, so he used to be used as a place of hope. This individual's reliability can be considered trustworthy when he can meet other individuals' needs. Categorizing trusted information sources involves processing individual pieces of information. An individual's ability to perform such information processing is known as heuristic and systematic system thinking (Chaiken \& Ledgerwood, 2012). Heuristic information processing involves an individual's ability to receive information briefly so that they only see things as they appear.

In contrast, systematic information processing is an individual's ability to receive information based on various in-depth information. Systematic information processing requires individuals to have the availability, accessibility, and applicability for their learning and experience. This ability requires stratified thought patterns when carrying out its activities. This understanding is in line with concept developed by Lankshear \& Knobel (2008) about four essential competencies of digital literacy, as follows: searching using search engines, hypertext navigation, bringing together knowledge, and content evaluation. It can be concluded that content evaluation and critical thinking are the most essential and most significant elements of digital literacy.

After considering trust in the source of information, the respondents then analyzed other matters relating to the information obtained in social media. If the information obtained does not address sensitive issues and has urgency, respondents are willing to share the information. The process of sharing such information is termed a repost. Repost is a behavior performed 
by an individual to re-share previously obtained information. In addition, respondents also consider sharing information vital because they receive information in exchange for the information they give. The exchange of information can be used to make further decisions as well as to discover new information. This finding aligns with Dong \& Deng's (2016) study that found that the desire to acquire or learn something encourages individuals to engage in information-sharing behavior. The respondents stated that they repost information because of their desire to share the information as the desire creates an interconnected relationship among the information media users. The interconnection relationship occurs when a person performs a repost, so the message (repost) can be read by the recipient (others). There is a possibility of reposting back to the recipient. Reposting for sharing information can be aligned with knowledge sharing. By sharing knowledge with others, individuals come closer to the behavior of knowledge creation (Helmi, 2010). When questioned about the reason they shared information, respondents' answers were consistent with Chen, Chang, \& Liu's (2012) findings that explained that knowledge-sharing behaviors included the dynamics of sharing motivation, incentive mechanisms, and satisfaction.

\section{Conclusion}

This study found that participants actively use social media to share information with one of its goals. Internet facilitates widespread and rapid information, both the positive side and its negativity. In anticipating the impacts, the real manifestation of this form of digital literacy is to cross (double) check. Participants find out about information obtained from social media by examining it through various reliable sources such as the validity of the website's appearance and the data contained in the information resource. By ensuring the data source's validity, participants then pass the information on to others (repost) with various motivations for showing concern for others.

\section{References}

Asosiasi Jasa Penyedia Internet Indonesia (APJII). (2016). Infografis Penetrasi dan Perilaku Pengguna Internet Indonesia (Infographic on Indonesian internet user penetration and behavior). Retrieved from https://apjii.or.id/downfile/file/surveipenetrasiinternet2016.pdf

Asosiasi Jasa Penyedia Internet Indonesia (APJII). (2018). Infografis Penetrasi dan Perilaku Pengguna Internet Indonesia (Infographic on Indonesian internet user penetration and behavior). Retrieved from https://www.apjii.or.id/content/read/39/410/Hasil-SurveiPenetrasi-dan-Perilaku-Pengguna-Internet-Indonesia-2018

Bawden, D. (2008). Origins and concepts of digital literacy in Digital literacies: Concepts, policies and practices. In C. Lankshear. \& M. Knobel (Eds). Digital literacies: Concepts, policies and practices. Peter Lang Publishing, Inc.

Chaiken, S., \& Ledgerwood, A. (2012). A theory of heuristic and systematic information processing. In P. A. M. Van Lange, A. W. Kruglanski, \& E. T. Higgins (Eds). Handbook of theories of social psychology. Volume 1. SAGE Publications Ltd. https://psycnet.apa.org/doi/10.4135/9781446249215.n13

Chen, C., Chang, S., \& Liu, C. (2012). Understanding knowledge-sharing motivation, incentive mechanisms, and satisfaction in virtual communities. Social Behavior and Personality, 40(4), 639-648. https://doi.org/10.2224/sbp.2012.40.4.639

CIGI-IpSos. (2017). Global survey on internet security \& trust. Retrieved from https://www.cigionline.org/internet-survey-2017 
Cresswell, J. (2009). Research design: Qualitative, quantitatice and mixed-method approaches. Third edition. SAGE Publications.

Dong, M., \& Deng, D. (2016). Effect of interns' learning willingness on mentors' knowledge sharing behavior. Social Behavior and Personality: An International Journal, 44(2), 221-232. https://doi.org/10.2224/sbp/2016.44.2.221

Eshet-Alkalai, Y. (2004). Digital literacy: A conceptual framework for survival skills in the digital era. Journal of Educational Multimedia and Hypermedia, 13(1), 93-106.

Hair, Jr., J., F. Black, W., C. Babin, B., J. \& Anderson, R., E. (2010). Multivariate data analysis, 7th edition. Pearson.

Helmi, A. F. (2010). Determinant perilaku inovatif (Determinant of innovative behavior). (PhD thesis). Universitas Gadjah Mada, Yogyakarta.

Kominfo. (2014). Riset Kominfo dan Unicef mengenai perilaku anak dan remaja dalam menggunakan internet (Kominfo and Unicef research on the behavior of children and adolescent in using the internet). Retrieved from https://kominfo.go.id/index.php/content/detail/3834/Siaran+Pers+No.+17-PIH

Krippendorff, K. (2004). Content nalysis: Introduction to its methodology. SAGE Publications Inc.

Lankshear, C., \& Knobel, M. (2008). Digital literacies: Concepts, policies and practices. Peter Lang Publishing, Inc.

Martin, A. (2005). A European framework for digital literacy: A progress report. Journal of ELiteracy, 2, 130-136.

Ng, W. (2012). “Can we teach digital natives digital literacy?" Computers \& Education, 59(3), 1065-1078. https://doi.org/10.1016/j.compedu.2012.04.016

Pietrass, M. (2007). Digital literacy research from an international and comparative point of view. Research in Comparative and International Education, 2(1), 1-12. https://doi.org/10.2304\%2Frcie.2007.2.1.1

Pratolo, B. W., \& Solikhati, H. A. (2020). The implementation of digital literacy in Indonesia suburban EFL classes. International Journal of Scientific \& Technology Research, 9(1), $1508-1512$.

Priwati, A. R. (2018). Cross (double) check dan repost: Manifestasi literasi digital di media social (Cross (double) check: Digital literacy manifestation in social media). (Master thesis). Universitas Gadjah Mada, Yogyakarta.

Rahmah, A. (2015). Digital literacy learning system for Indonesian citizen. Procedia Computer Science, 72, 94-101. https://doi.org/10.1016/j.procs.2015.12.109

Ramdhani, N., Wiradhany, W., \& Rachmayani, D. (2013). Pengembangan alat ukur literasi digital (Development of digital literacy measurement). Temu Ilmiah Nasional 3. Jakarta: Universitas Tarumanagara.

Sharma, R., Fantin, A., Prabhu, N., Guan, C., \& Dattakumar, A. (2016). Digital literacy and knowledge societies: A grounded theory investigation of sustainable development. Telecommunications Policy, 40(7), 628-643. https://doi.org/10.1016/j.telpol.2016.05.003

Suwana, F., \& Lily. (2017). Empowering Indonesian women through building digital media literacy. Kasetsart Journal of Social Sciences, 38(3), 212-217. https://doi.org/10.1016/j.kjss.2016.10.004

Tapscott, D. (2009). Grown up digital: How the next generation is changing your world. McGraw-Hill.

Van Deursen, A. J. A. M., \& Van Dijk, J. A. G. M. (2009). Using the internet: Skill related problems in users' online behavior. Interacting with Computers, 21(5-6), 393-402. https://doi.org/10.1016/j.intcom.2009.06.005 
Walther, J. B. (2011). Theories of computer-mediated communication and interpersonal relations. In M. L. Knapp \& J. A. Daly (Eds). The Handbook of Interpersonal Communication. SAGE Publications Ltd.

Wanandhi, R. S. (2016). Literasi digital dan kontrol diri sebagai prediktor terhadap internet addiction pada mahasiswa (Digital literacy and self-control as predictors of internet addiction among undergraduate students). (Undergraduate thesis). Universitas Gadjah Mada, Yogyakarta.

Warschauer, M. (2009). Digital literacy studies: Progress and prospects. In M. Baynham \& M. Prinsloo (Eds). The future of literacy studies. Palgrave Macmillan.

Wood, J. T. (2009). Communication in our lives. Fifth edition. Wadsworth Cengage Learning. 